\title{
The Danish Paradox: Intolerance in the Land of Perpetual Compromise
}

\author{
Thorfinn Stainforth
}

\begin{abstract}
What explains the apparent contradiction between Denmark's reputation as a liberal, tolerant society, and the recent rise in wide-spread xenophobia there? The root causes of the present wave of xenophobia are fundamentally similar to the rest of Europe: they grow primarily out of the tensions inherent in the transition from an industrial to postindustrial society. However, its unusual virulence across an apparently inclusive mainstream political spectrum, and departure from the established norms in the country, is an outgrowth of the present challenge to the egalitarian, anti-modern ethos that has steered Denmark toward its present state. Modern Danish nationalism, heavily influenced by the ideas of N.F.S. Grundtvig, has emphasized anti-elitism, decentralization, and egalitarianism. However, for the first time since at least the 1920s these political cornerstones are being seriously challenged and re-examined. Immigration has become one of the symbols of, and primary battlefield in, the challenge to the social consensus that has existed throughout most of the 20th century.
\end{abstract}


On February $4^{\text {th }}$ and $5^{\text {th }}$, 2006 the Danish embassies in Beirut and Damascus were set ablaze by angry mobs. In the weeks preceding and following, Danish flags were repeatedly burned by angry protestors, hundreds were killed in violent demonstrations, Danish goods were boycotted, ambassadors were withdrawn, and Danish citizens were advised not to visit primarily Islamic countries for fear of violence. To many observers, particularly in the West, the spectacle seemed quite ludicrous.

Denmark has a reputation as a liberal, open-minded, peaceful, and generous nation: a paragon of civilization and moderation. On balance this reputation is fairly well deserved: Denmark has a commitment to multilateral institutions, an unusually generous foreign aid programme, a well educated population, an open media, and a comprehensive welfare system. The violent rhetoric and images directed toward this country would be almost laughable, were the consequences not so serious. However, such violence and depth of emotion do not arise out of nothing — Danes, a group of Danes at any rate, did provoke the violent reaction. The crisis was merely the most dramatic expression of a recent trend toward ethnic conflict and the rise of a strong current of xenophobia in Denmark. The country's recent treatment of immigrants from outside the EU or Nordic countries does not fit its tolerant reputation. Today, Denmark has some of the world's toughest restrictions on immigration; the government depends on the support of an overtly xenophobic, and many would argue racist party, the third largest in parliament; ethnic street violence is not uncommon; nationalist and almost racist rhetoric appears on a frequent basis in the press, and even the left wing of the political spectrum does not always forcefully counter racist discourses as it has in many other countries. ${ }^{1}$ The result is a situation of distrust and low-level conflict between many recent immigrants and much of the established population.

What are we to make of the contradiction between the imagery of Danish society as almost uniquely pacific, civil, tolerant, and inclusive, with the remarkable recent

\footnotetext{
${ }^{1}$ See, Peter Hervik, 'The Emergence of Neo-nationalism in Denmark,' in Neo-Nationalism in Europe and Beyond: Perspectives from Social Anthropology, eds. André Gingrich and Marcus Banks (New York: Berghahn Books, 2006), 92-106. and Clarissa Berg and Peter Hervik, “"Muhammedkrisen.” En politisk magtkamp i dansk journalistisk.,' The Academy for Migration Studies in Denmark, AMID Working Paper Series 62/2007.
} 
success of xenophobic discourses and parties in Denmark? The positive imagery and reputation are not undeserved. Denmark has been an extraordinarily peaceful and successful society by any number of measurements for most of the past century. Its peacefulness has been particularly notable during a violent century in Europe. Liberal democracy and the rule of law have had a particularly strong hold — almost no fascist groups developed even at the height of the phenomenon in Europe, and the country has been free of fundamentally divisive political conflicts since the 1940s.

In other countries with more overtly nationalistic, heterogeneous, or insular histories, a xenophobic reaction to foreigners might be more expected, and perhaps easily acknowledged by their populations. However, in Denmark, ethnic homogeneity and the re-emergence of an age-old societal split, which has lain dormant for much of this century, makes the accommodation of new societal groups unusually difficult. Although Denmark has a reputation as a bastion of equality and civilization, foreign observers would do well to remember the historical roots of this phenomenon. The new less tolerant picture of Denmark is a logical by-product of the same forces that created egalitarian Denmark.

Of course, xenophobia is a general phenomenon in Europe today, and has arisen along similar lines in many countries across the continent. Racist discourse is common across the continent, and anti-immigrant parties have had considerable success in the last twenty years, notably in Austria, Belgium, France, Italy, Norway, Switzerland and the Netherlands. ${ }^{2}$ A consensus seems to have emerged that the rise of xenophobia, and certainly its most overt political expression in the so-called "Radical Right Wing Populist Parties” (RRP) is a result, fundamentally, of the transition from an industrial economy to a post-industrial one. This process has had at least two pivotal effects, as Jens Rydgren explains:

First, traditional working class milieus have been decomposed, as a result of both the shrinking size of the industrial sector and the increased diversification of the working class, being the result of specialisation and a growing demand of technical skills. As a sign of this development we see declining levels of class voting,

\footnotetext{
2 Jens Rydgren. “Introduction.” Movements of Exclusion. (Hauppauge: Nova Science Publishers, 2005), p. $1-25$.
} 
especially among young workers. Second, the postindustrialisation process has created new 'loser groups' - not coping with the increased demands of education, internationalisation and flexibility - which are prone to support political programmes promising a return to the stable values and virtues of 'the status quo ante'.

This is a phenomenon broadly observable across the continent, and goes some of the way to explaining the xenophobia seen today. However, this still leaves open the question of why some countries have seen parties gain significant influence running on anti-immigrant policies, while others, Sweden for example, have not. Here researchers have not found a consensus, but have identified several factors that seem to be important, including: the degree of policy convergence of traditional parties, the speed of adaptation of existing parties to new social cleavages, public trust in politicians, media attitudes, the degree of institutional openness to new ideas and parties, international examples, the state's capacity for repression, and the voting system in use. ${ }^{4}$

Those are all important issues to be examined when studying the institutionalization of xenophobia through political parties. The growth of xenophobia and the success of those discourses in Denmark share many of these same immediate causes as in the rest of the continent. However, this paper will turn to the history and particularities of Danish nationalism, the same forces that resulted in the country's characteristic egalitarianism and social-inclusiveness, as an explanation for the dramatic and successful growth of xenophobia there.

\section{Traditional Danish Nationalism}

The most important single factor in the apparent discrepancy between typical Danish openness and attitudes toward immigrants, particularly Muslim immigrants, lies

\footnotetext{
${ }^{3}$ Jens Rydgren, "Explaining the Emergence of Radical-Right Wing Populist Parties: The Case of Denmark,” West European Politics (Spring 2004) 27:3, 478. (474-502).

${ }^{4}$ See, Kitschelt \& McGann (1995), McAdam (1996), Kriesi et al (1995), and Rydgren (2003) for discussion.
} 
in the peculiarities of Danish nationalism. This peculiarity stems from the foundations of modern Danish nationalism in the mid- $19^{\text {th }}$ century following a series of geo-political failures for the Danish state. The result was a blend of the previous national culture based on Lutheranism, traditional state patriotism of the composite monarchy, and a new peasant "folk" nationalism. These three strands of self-understanding have competed in Denmark in some way since the late $18^{\text {th }}$ century, ${ }^{5}$ but it wasn't until the mid $19^{\text {th }}$ century that their conflict was articulated in its modern form.

The newer "folk” ideology emphasized a romantic idea of Danish “smallness", self-sufficiency, innate cultural traditions, and a collective national spirit and community. ${ }^{6}$ Although not completely unusual — a similar form of nationalism is also seen in Eastern Europe - these ideas were unusually successful in permeating mass consciousness in Denmark, and differed from the earlier “patriotic nationalism” more common in Western Europe. ${ }^{7}$ Nationalism of this type is common to Scandinavia, but important differences exist between countries, especially between Denmark and Sweden. This newer form of nationalism has dominated Danish culture and politics for most of the $20^{\text {th }}$ century, largely, but not completely, displacing the earlier strands. ${ }^{8}$

Danish nationalism emerged as a mass phenomenon around 1848, coinciding roughly with the Schleswig-Holstein War and then the loss of those two duchies, followed by the end of absolutism in Denmark. The trauma of losing these territories, some of the richest within the kingdom, reinforced the trends already apparent in Danish nationalist thought. The loss of the duchies was only the most recent in a series of territorial losses for the Danish state going back a couple of hundred years. Much of the nationalist emphasis can be summarized in a popular slogan of the time, "What we lost

\footnotetext{
${ }^{5}$ Ole Feldbæk, 'Clash of Culture in a Conglomerate State: Danes and Germans in 18th Century Denmark,' in Clashes of Cultures, ed. C.V. Johansen and P.E. Ladewig (Odense: Odense University Press, 1992), 80 93.

${ }^{6}$ L. Yahil. "National pride and defeat: A comparison of Danish and German nationalism.” Journal of Contemporary History, (September 1991), Vol. 26 Issue 3/4, p453.

${ }^{7}$ Uffe Østergård, “The Danish Path to Modernity,” Thesis Eleven 77 (May 2004), 25.

${ }^{8}$ Benedikte, Bricker. “A 'Small Great National State': An Analysis of the Cultural and Political Factors that shaped Danish Nationalism 1760-1870. Journal of Historical Sociology, (December 2003), Vol. 16 Issue 4, p. 407-431.
} 
externally, we shall gain internally."9 It was an explicit rejection of the traditional elitedriven, multi-ethnic Danish state.

Nicolai Frederik Severin Grundtvig is the figure most associated with the formation of modern Danish nationalism and national consciousness. One biographer argued that no other man "has meant so much to Denmark as N.F.S. Grundtvig — no one had so much all around significance as he did.” ${ }^{10}$ He was a priest and a poet who came to prominence early in the $19^{\text {th }}$ century. Although he was a strong Christian, he rejected the “enlightenment ideology” of rationalism that dominated the Lutheran church at the time, which he felt robbed the church of its soul. ${ }^{11}$ He often fought with the Church hierarchy — he was even barred from preaching for a time — but he eventually gained followers and acceptance within the government and church. He even played a role in writing the new constitution in $1848 .{ }^{12}$

He argued that to be a good Christian a person had to be profoundly self-aware; in order to be properly self-aware the believer had to be in touch with his or her cultural and historical background. He believed that every people had a unique "folk spirit”, through which its members could find their true nature. This background, or "folk spirit" was expressed most clearly in traditions such as song, dance, language, literature and so on. He, and his growing number of followers, valued the eccentricities of local customs, legends (such as Norse mythology), dialects, self-sufficiency, tight communities, and distrusted "foreign" influences such as were often found in Copenhagen, for example at the university. ${ }^{13}$

This mode of thinking became very important in the formation of Danish national consciousness - in the formation of the imagined community of Denmark. ${ }^{14}$ It grew initially out of the countryside, propagated by a class of wealthy land-holding peasants through a concrete political programme. Although Grundtvig believed in an "organic"

\footnotetext{
${ }^{9}$ Brincker, 424.

${ }^{10}$ Yahil, 454.

${ }^{11}$ Buckser, Andrew. "Rescue and Cultural Context During the Holocaust: Grundtvigian Nationalism and the Rescue of Danish Jews,” Shofar 19:2 (2001) p. 16.

${ }^{12}$ Ernest Stabler, Innovators in Education 1830-1980 (Edmonton: University of Alberta Press, 1986), 4.

${ }^{13}$ Buckser, 17.

${ }^{14}$ Benedict Anderson, Imagined Communities, (London: Verso, 1991).
} 
form of nationalism, he, and his followers, set up institutions that were important in building a sense of "Danishness" across the country. First were "folk high schools" which emphasized the importance of the folk spirit, the Danish language, egalitarianism. The schools' purpose was quite explicitly to help "awaken the inner spirit” of the Danish peasants; to help them realise their full potential, and to compete with the educated class in Copenhagen. ${ }^{15}$ This class came to play a very important role in the ensuing political struggles and societal transformations. ${ }^{16}$ Flowing in part from this model of education came the highly successful agricultural cooperatives, which helped reinforce the independence and importance of peasant farmers. ${ }^{17}$

Another reason for the successful diffusion of Grundtvigian nationalism was an effective campaign of promoting national symbolism. ${ }^{18}$ Starting around the time of the loss of the duchies in 1864, the Danish flag, for example, was used with unusual frequency in the most banal situations as a form of "solidarity" with the Danes living in Germany; this highlighted Grundtvigian nationalism to the general population. Today the flag continues to appear regularly at children's birthday parties, religious festivals of all kinds, blow out sales, flying in back gardens, decorating food, on kitchen ware, and in many other everyday places. ${ }^{19}$ In line with Michael Billig's theory of banal nationalism, ${ }^{20}$ this flagging has helped to identify "Denmark” with house and home, hospitality, family, local businesses, and other familiar aspects of daily life, reinforcing the power of the “people's” Denmark as an imagined community. The flagging has helped to familiarize all aspects of the Danish state, to identify if with peoples' lives, and thereby built an unusually strong sense of national solidarity.

Because of late $18^{\text {th }}$ century property reforms which had allowed for the creation of a relatively large property owning class of peasants, the economic success of

\footnotetext{
${ }^{15}$ Steven M. Borish, The Land of the Living: The Danish Folk High Schools and Denmark's Non-Violent Path to Modernization (Nevada City: Blue Dolphin Publishing, 1991), 203.

${ }^{16}$ Povl Bagge, 'Nationalisme antinationalisme og nationalfølelse i Danmark omkring 1900,' in Dansk identitetshistorie 3: Folkets Danmark 1949-40, ed. Ole Feldbæk (Copenhagen: Reitzels Forlag, 1992 ), 456.

${ }^{17}$ Brincker, 415.

${ }^{18}$ Brincker, 414.

${ }^{19}$ Wren, 149.

${ }^{20}$ Michael Billig, Banal Nationalism, (London: Sage, 1995).
} 
cooperatives, and the cultural and educational success of folk high schools, a class of wealthy peasants came to dominate the small and largely agricultural country. The “urban” elite of the suddenly smaller and democratising unitary nation state, was not able to resist the political power of the reorganised peasant classes. Unlike in many other countries, the urban working class, such as it was, allied with the peasants and participated in their political and cultural discourses, mostly because of its relatively small size. ${ }^{21}$

Grundtvigianism had permeated Danish society to such an extent by 1913 that the Social Democrats explicitly adopted it as their ideology too..$^{22}$ Although the original Grundtvigians, and many in the cooperative movement, did not consider urban labourers to be part of the "real” Danish people, their ideas had sufficiently influenced Danish industrial society, which also relied primarily on small-scale production, that they were essentially co-opted. The Social Democrats, the party of the urban labourer, accepted the power of the prosperous peasants, again reflecting their dominance, but extended their ideology to the whole country, incorporating the urban working class as the "backbone" of the Danish people. Their ideological revision was compatible with Grundtvigianism, and borrowed most of its themes, but was not identical. It stressed the land and the people, but put renewed emphasis on the ability of the people to "build" their own society in their own land. ${ }^{23}$

Working together, the Liberals (Venstre), and the Social Democrats revised the constitution in 1915 marking a victory against the older, patriotic, elitist school of thought, born out of the composite state. The revision marked a return to the spirit of the 1848 constitution after the reactionary amendments of $1866 .{ }^{24}$ The 1915 constitution marked a transition to a more inclusive form of democracy and the beginnings of the ideological hegemony of the "folkist/Grundtvigian" school. The compromises made by

\footnotetext{
${ }^{21}$ Østergård, 37.

${ }^{22}$ Østergård, Path to Modernity, 36.

${ }^{23}$ Lene Hansen, 'Sustaining sovereignty: the Danish approach to Europe,' in European Integration and National Identity: The Challenge of the Nordic States, ed. Lene Hansen and Ole Wæver (London: Routledge, 2002), 60.

${ }^{24}$ In the years after the original constitution, its more radical reforms and provisions were gradually whittled away, and the 1866 constitution marked a victory for conservative forces.
} 
the Social Democrats, and their acceptance of rural power prevented their own domination of the state (as in the case of their sister parties in Sweden and Norway), but was critical to ensuring social peace for the $20^{\text {th }}$ century. ${ }^{25}$ The party simply recognized that it would not be able to hold onto power without reaching some sort of accommodation with the Liberals. This bargain, between the urban labourer and the wealthy peasants marks the beginnings of the ideological hegemony of Grundtvigianism in Denmark. ${ }^{26}$

Grundtvigian thought was strongly contested in the late $19^{\text {th }}$ century and into the $20^{\text {th }}$. The Lutheran culture of Denmark, which had existed in a similar form from the time of the reformation until Grundtvig’s time, emphasized conformity and social cohesion to a large degree. The reformation had been unusually state driven in Scandinavia, and the "top-down" nature of the project had prevented the social fracturing that had occurred in Germany and the Netherlands. As a result, state and church were unusually united, helping to develop a strong national consensus with regards to morality, law, and institutions. The resulting mentality in much of the population emphasized solidarity, but also conformity. ${ }^{27}$ This aspect of the existing culture adapted itself relatively easily to Grundtvigianism, although tension existed between its conformity and respect for institutions, and the populism and individualism of the newer ideology.

However, elite, conservative groups, such as civil servants, the urban bourgeouisie, the monarchy, and the remnants of the aristocracy clung to an older patriotic nationalism based on the idea of Denmark as a top-down composite state. Until the 1920s at least, the "Right” party (Højre), and its successor the Conservative People’s Party, representing mainly the landed nobility and other conservative elements, advocated a less "people/folk" oriented vision of Denmark. ${ }^{28}$ They promoted "the defence movement” which advocated a strong Danish military, capable of fighting Germany long

\footnotetext{
${ }^{25}$ Østergård, Path to Modernity, 37.

${ }^{26}$ Østergård, 35.

${ }^{27}$ Henrik Stenius, 'The Good Life is a Life of Conformity: The Impact of Lutheran Tradition on Nordic Political Culture,' in The Cultural Construction of Norden, ed. Øystein Sørensen and Bo Stråth (Oslo: Scandinavian University Press, 1997), 163.

${ }^{28}$ Tim Knudsen, Da demokrati blev til folkestyre: Dansk demokratihistorie I (Copenhagen: Akademisk Forlag A/S, 2001), 114.
} 
enough for political manoeuvring from great power allies to promote Denmark’s objectives, namely the establishment of the Dano-German border at the Ejder River and incorporating large German speaking areas into the Danish state, against their will. This cleavage in Danish society became a fundamentally defining "anti-elite” and anti-modern one, which would have strong ramifications through the century. Grundtvigianism would become so successful, and its core anti-elite, and especially anti-modern message, so ingrained, that it has a profound impact on politics today.

Questions surrounding the Danish state's attitude toward the Duchies after the First World War marked the final struggle concerning the nature of the Danish state. The conservative faction, espousing a pre-Grundtvigian notion of the nation pushed for an aggressive attitude, still hoping to re-incorporate largely German speaking areas, for example the relatively large city of Flensborg. The King was sympathetic to this position, and he attempted to intervene by naming a new government, not based on the elected parliament, which would have pursued a conservative line. In the ensuing "Easter crisis" the King was finally forced to recognize the legitimacy of the parliament as the basis of Danish government, which had so far been a point of contention with the monarchy. As it turned out, a non-military policy was relatively successful. In northern Schleswig, where Danish language teaching was forbidden, and the German state officially tried to Germanize the population, Grundtvigian thought and institutions were crucial in maintaining Danish feeling until 1920 when a plebiscite returned it to the Danish state. ${ }^{29}$ This was perceived as a victory for the Danish “people” as a cohesive group resisting the outside world. Although traditionalists were disappointed that Flensborg and other primarily German areas remained as part of Germany, the question was largely settled in the popular imagination..$^{30}$

This apparent victory for “the people’s” Denmark, coming as it did through their self determination, and cultural autonomy, contrasting with the military disasters of 1864, convinced many that Denmark should pursue an actively “anti-power politics.” This politics of patience, negotiation, and non-confrontation led to a broad consensus on

\footnotetext{
${ }^{29}$ Buckser, 19.

${ }^{30}$ Hansen, Danish Approach to Europe, 58.
} 
Denmark's role in Europe, as well as final acceptance of the Grundtvigian "people” across the political spectrum. ${ }^{31}$ Final remnants of the old-school objections to the new democratic, limited Denmark apparently disappeared during the Second World War when the monarchy and population rallied behind the symbols of Danish smallness and democracy in the Grundtvigian tradition. ${ }^{32}$

The ideological congruence between the Social Democrats and the Liberals, and the acceptance of “anti-power politics” starting in the 1920s established a cultural and political hegemony which now marks almost all aspects of Danish life. The Social Democrats were successful in establishing a social welfare state more or less on their terms, and that social welfare state is now strongly associated with the Danish state itself. In fact, hardly any elements of the political spectrum question the fundamentals of the welfare state, although they may attack details of it. It is now seen, by many, as an expression of solidarity and respect for the individual in the Grundtvigian tradition. It is also seen, by many, as explicitly superior to rival models in the rest of Europe. ${ }^{33}$

However, the schism in Danish society between elite and popular has never disappeared, manifesting itself in subtle ways for the last half century. Though it has enjoyed a long ascendancy, it seems that some of the assumptions of the Grundtvigian model are being challenged by different facets of globalization, both economic and cultural. Some of the older strains of elite discourse are re-emerging in the first serious challenge to the Danish societal model in sixty or seventy years. This duality of the Danish national culture is aptly symbolized in the use of two national anthems: one, more militaristic, derived from the earlier composite state era, and the other, romantic and humble, from the post-Grundtvigian, homogeneous Denmark. ${ }^{34}$

\footnotetext{
${ }^{31}$ Knudsen, demokrati til folkestyre, 145.

${ }^{32}$ Henrik S. Nissen, 'Folkelighed og frihed 1933: Grundtvigianernes reaktion på modernisering, krise og nazisme,' in Dansk identitetshistorie 3: Folkets Danmark 1949-40, ed. Ole Feldbæk (Copenhagen: Reitzels forlag, 1992), 673.

${ }^{33}$ Richard Jenkins, 'Not Simple At All: Danish Identity and the European Union,' in An Anthropology of the European Union, ed. Irène Bellier and Thomas M. Wilson (Oxford: Berg, 2000), 167.

${ }^{34}$ Tim Knudsen, 'A Portrait of Danish State-Culture: Why Denmark Needs Two National Anthems,' in European Integration and Denmark's Participation, ed. Morten Kelstrup (Copenhagen: Copenhagen Political Studies Press, 1992), 262.
} 


\section{Grundtvigian Nationalism and the Politics of Xenophobia}

Some writers believe that Grundtvigian nationalism was vital in shaping the Danish response to Nazi persecution of Jews in Denmark during the Second World War. ${ }^{35}$ Andrew Buckser explains:

the Jews had long maintained their own culture, their own language, and their own religious beliefs despite political disenfranchisement and geographic dispersion. They had done so in ways which Grundtvig would have found very appealing. They had cultivated an ancient ancestral language; they had maintained their rituals and celebrations; they had held close to the religious beliefs of their ancestors... and the predicament of the Jews during the war mirrored that which the Grundtvigians imagined for the Danes. ${ }^{36}$

The Danish population's reaction to the situation of the Jews is often considered to be unique amongst the peoples of Europe. Academics have had some trouble explaining the spontaneity and solidarity of the rescue despite the fact that anti-semitism had been widespread in the country before the war. The key to the rescue, along with geographic and political realities such as the proximity of neutral Sweden, or the unusually lenient attitude of German authorities, lies in the empathy felt by many Danes for another small ethnic group struggling for self-preservation during the war.

How then can we explain the current reactions to refugees and other immigrants? A population heavily influenced by Grundtvigian respect for tradition, moved to protect a persecuted minority might be expected to be charitable toward Bosnian or Somali immigrants fleeing war and persecution. However, the evidence indicates that relations between ethnic Danes and recent immigrants are strained. ${ }^{37}$ Many Danes are openly suspicious of immigrants, particularly Muslims. The Danish People’s Party, running on

\footnotetext{
${ }^{35}$ Yahil, 454.

${ }^{36}$ Buckser, 21.

${ }^{37}$ Anders Linde-Laursen, 'Is something rotten in the state of Denmark? The Muhammad cartoons and Danish political culture,’ Contemporary Islam 1:3 (2007): 265.
} 
an explicitly anti-immigrant platform is now the third largest party in parliament, and its votes are vital to the Liberal/Conservative coalition government.

Interestingly though, the relationship between the established Danish population and the immigrants was not always so adversarial. When relatively large numbers of immigrants first came to Denmark in the late 1960s, many report feeling welcomed by the population. One Turkish woman described her experience:

It was a bit strange and there were hardly any foreign workers and dark-haired people and such like, so they thought we looked very nice and we got sweets and we got money and we got bikes and we got clothes and everyone clapped their hands because we looked so nice. It was a lovely time the first two years. ${ }^{38}$

This passage reflects some of the paternalism of the time, but also the openness and good relations between the groups. Public opinion, as reflected in the media, was mixed on the idea of mass-immigration, but not overtly hostile to foreigners. Employers, and even some unions accepted the idea of importing foreign workers in aid of the labour shortage.$^{39}$ However, within a few years hostility increased and the government restricted immigration procedures, partially in response to social pressure. In 1973 it froze all nonrefugee immigration, largely due to the economic problems brought on by the oil crisis. ${ }^{40}$

The early acceptance of immigrants might be explained by the good economic times, or the Danish economy's need for workers. The immigrants were not seen as a burden on Danish society yet. Perhaps it was because of their newness, and relatively low numbers. ${ }^{41}$ They could still be viewed as a curiosity, not a fixture in Danish life. Many

\footnotetext{
${ }^{38}$ Karen Wren, “Cultural racism: something wrotten in the state of Denmark?” Social and Cultural Geography, Vol. 2 No. 2 (2001), 145.

${ }^{39}$ Bent Jensen, “Thirty years of press debate on 'the foreigners' in Denmark Part I: Migrant and guest workers, 1963-80,” in Immigration to Denmark: Intrenational and national perspectives, eds. David Coleman and Eskil Wadensjö, (Aarhus: Aarhus University Press, 1999), 199.

${ }^{40}$ Søren Pedersen, “Migration to and from Denmark during the period 1960-97,” in Immigration to Denmark: Intrenational and national perspectives, eds. David Coleman and Eskil Wadensjö, (Aarhus: Aarhus University Press, 1999), 199.

41 Pedersen, 151.
} 
Danes thought that the "foreigners" would go home when their jobs finished, as many had not yet brought their families with them to settle. ${ }^{42}$

This initial reaction to immigrants can also be explained by a Grundtvigian interpretation of Danish nationalism. At this time immigrants were still so few in number and so remote from most Danes’ daily experiences that they could still belong to a category of foreign people, whose customs and lives had little impact on Danish society. They were no threat to the "spirit" of the Danish people; immigrants did not interrupt the homogenous traditions of an essential Denmark. The dominant concerns were economic, as reflected by the Danish press and government. ${ }^{43}$ As can be seen in the remarks of the Turkish woman, Danes were impressed and amused by the peculiarities of the foreigners, treating them like curious children, with no overt racism.

As the 1970s and especially the 1980s wore on, the tone of relations became increasingly negative. Media and press reports reported more and more on the problems of immigration to the point that this discourse came to be a dominant theme in the Danish press. ${ }^{44}$ Studies have shown that a large majority of news stories on immigrants focus on crime, social problems, or conflict with Danish society, especially in, but not limited to, popular tabloids and right leaning broadsheets. Often the coverage even breaches the organizations’ own codes of ethics. This phenomenon is well known, and has been pointed out by numerous international organizations such as the European Union, the Council of Europe, the International Federation of Journalists, and others, but these criticisms have been generally disregarded. ${ }^{45}$

A new protest party, the Progress Party of Mogens Glistrup, founded in 1972, helped to politicize Islamic immigration, framing it as a threat to Danish society. ${ }^{46}$ The party did not pick up on anti-immigrant issues in a big way until the 1980s when its fortunes were waning. The Progress Party made calls to expel all Muslims, and various

\footnotetext{
42 Jensen, 191-251.

43 Jensen, 191-251.

${ }^{44}$ Wren, 155.

${ }^{45}$ Mustafa Hussain, “Islam, Media and Minorities in Denmark,” Current Sociology, October 2000, Vol. 48(4): 110.

${ }^{46}$ Hussain, 99.
} 
party members have frequently made blatantly racist remarks, for example calling Muslims “mad dogs” or saying that they "breed like rats.” ${ }^{47}$ The Progress Party never had as much success when running its xenophobic campaign as its successor, the Danish People's Party, probably because of its lack of appeal in the working class due to its opposition to the welfare state, and because of its explicit appeals to biological racism. ${ }^{48}$

In 1986 another influential new group, The Danish Society (Den Danske Forening), was founded, to reform Danish immigration laws and drastically cut the number of immigrants. The society was also an important factor in framing immigrants, especially Muslims, as a problem for Danish society. Several of its members went on to become members of parliament; one member, Søren Krarup, became a well-known opinion leader. The group launched a campaign to flood newspapers with anti-immigrant letters.

This all occurred during a time that the number of "family class" immigrants, family members joining immigrants already in Denmark, and above all refugees, increased dramatically. Although the 1973 immigration "freeze" remained in effect, the Danish parliament passed a new immigration law in 1983. This act continued to limit economic immigrants severely, but actually increased the rights of refugees. Previously, only refugees recognized under the Geneva Convention were granted status in Denmark, but under the new law, de facto refugees were also recognized. As a result, the recognition of refugees increased dramatically: 16,374 refugee claims had been accepted between 1956 and 1984, but in the four years between 1985 and 1989, 26,352 were accepted. ${ }^{49}$ Denmark gained a reputation for having a very liberal refugee policy because of this law. However, it should be noted that the total foreign-born population, or foreign descended population, remained on the low end of European norms at about 3\%. ${ }^{50}$

Nonetheless, the law drew a great deal of criticism, with some commentators making extrapolations of how long it would be before Denmark became a majority

\footnotetext{
${ }^{47}$ Bashy Quraishy and Tim O’Connor, “Denmark: no racism by definition,” Race \& Class, 32 (3) (1991), 118.

${ }^{48}$ Jens Rydgren, "Explaining the Emergence of Radical Right-Wing Populist Parties: The Case of Denmark,” West European Politics Vol. 27:3 (May 2004), 487.

${ }^{49}$ Pedersen, 164.

${ }^{50}$ Hussain, 97.
} 
Muslim country under the new law. Many picked up on the theme that Denmark was being swamped by its own generosity, and that it was taking in far more refugees than were its "fair share" to the detriment of its own population at a time of economic stagnation. However, it was also a time when the numbers of people applying for refugee status in Europe had also increased significantly due to political instability and population growth in source countries. ${ }^{51}$

Over the late 1980s and early 1990s the government slowly added new restrictions to the immigration act in response to public pressure. However, the number of refugees granted status did not go down appreciably. Pressure continued from many actors in society to further limit immigration. During the war in Yugoslavia, many thousands of immigrants came to Denmark, further focusing attention on the issue. By the mid 1990s the Progress Party was in disarray and was replaced by the Danish People’s Party (DPP), a party even more focused on immigration issues.

The DPP had an enormous influence. Led by popular Pia Kjærsgaard, a more likable figure than Mogens Glistrup, it quickly took the place of the Progress Party as the “anti-establishment party.” Already in its first election it became the fourth largest party in parliament, followed by an even better showing in the revolutionary election of 2001 in which it became the third largest party. More importantly, it became the centre-right coalition government's support party. The government turned to the DPP to pass most of its legislation, which required some concessions on immigrant policy. At the same time, the popularity of the DPP had led the Liberal and Social-Democratic parties to take a more exclusionary tone as well in an attempt to keep their voters. ${ }^{52}$

Under the government of Anders Fogh Rasmussen, the Danish government tightened up immigration procedures considerably. While Denmark had been known for its liberal refugee laws in the 1980s, it came to be known for unusually harsh laws at the turn of the millennium. Various international organizations, such as the UNHCR and Amnesty International criticized the changes. ${ }^{53}$

\footnotetext{
${ }^{51}$ Pedersen, 163.

52 Hussain, 97.

${ }^{53}$ Eva Østergaard-Nielsen, “Counting the Cost: Denmark’s Changing Migration Policies,” International Journal of Urban and Regional Research, Volume 27.2 (June 2003), 454.
} 
The Danish left-wing has been hobbled by the immigration issue. Studies have shown that a large portion of DPP voters are former Social Democrats, working class and in favour of the welfare state. ${ }^{54}$ By attacking the Social Democrats' “elitism” and supposed catering to immigrants, the DPP managed to topple the "natural ruling party" from its position as the largest party in parliament. ${ }^{55} \mathrm{~A}$ schism has arisen within the Social Democratic Party over how to respond to this threat to their base. However, the general tendency has been to try to be seen as "getting tough” on immigrants. The Danish left has, in general, not confronted the racist rhetoric of the DPP, media, and various organizations. Rather, left-wing intellectuals and politicians have generally participated in these discourses, talking about the Muslim "threat to women” and by extension, Danish society. ${ }^{56}$

The factors that created the DPP, the Danish Society, left wing apathy toward minorities, and Muslim alienation are the same that have shaped Danish society for a hundred years, including the generally lauded egalitarianism and the rescue of Denmark's Jewish population. Although a Grundtvigian inspired society has great potential for egalitarianism and outward tolerance, it also has a homogenizing tendency, defensiveness, and “othering” capability, as many forms of nationalism do. ${ }^{57}$ From a liberal, egalitarian perspective, this model of nationalism has served Denmark fairly well for over a hundred years, but it has had some downsides, for example a fairly real racism manifested toward the few visible minorities in Denmark such as Greenlanders, drives for “ethnic and genetic purity” through sterilization programmes, ${ }^{58}$ and a strong and often remarked social conformity mechanism, manifested for example in Janteloven, which describes an attitude hostile toward anyone who tries to be different, or who is perceived as thinking too highly of themselves. However, the apparent success of Danish society and a possibility of escape in the form of emigration to the New World, kept potential

\footnotetext{
${ }^{54}$ Daniel Skidmore-Hess, “The Danish Party System and the Rise of the Right in the 2001 Parliamentary Election,” International Social Science Review, 2003, Vol. 78 Issue 3/4, 98. p. 89-110.

${ }^{55}$ Rydgren, 487.

${ }^{56}$ Wren, 158.

${ }^{57}$ Allan Pred, Even in Sweden: Racism, Racialized Spaces, and the Popular Geographical Imagination, (Berkeley: University of California Press, 2000), 27.

${ }^{58}$ Wren, 145.
} 
conflicts more or less under control. The presence of a relatively large population, unresponsive to the mechanisms of Grundtvigian society, has for the first time really tested this model of nationalism, and exposed some of its weaknesses in a modern globalized context.

A great deal of the concern in Denmark focuses exclusively on Islamic immigration, rather than immigration in general. Often people will talk about immigration in general, when it is clear by their words that they mean Islamic immigration. ${ }^{59}$ This is certainly partially a result of most immigrants being Islamic. However, there are also some sizable non-Islamic groups such as Tamils and Vietnamese. Some of this attitude is derived from world events, such as Islamic terrorism, or “fundamentalist” Islamic movements that receive a lot of attention in Denmark. These events feed a general perception already existing in Denmark that Islam is a pre-modern, barbaric religion. However this arose, the key fact to consider is that Islam is often seen as a threat to Denmark. Some politicians, such as Mogens Glistrup, have expressed a belief that there is an Islamic plot to infiltrate Denmark in order to spread the religion. ${ }^{60}$

The key differences between the Muslim and Jewish minorities are that the Jewish population is small, long established, and thoroughly integrated into the general population. It is also interesting to note that since the Second World War, when the Danish population came to sympathize with the Jews, anti-semitism has all but disappeared from Denmark. ${ }^{61}$ However, prior to the war anti-semitism had been a feature of life, though not on the same scale as in much of continental Europe. Had the Second World War not occurred, it is likely that Denmark's Jews would still face mild antisemitism. The historical anomaly of German occupation and oppression of the Jews helped to legitimise their plight in a way that Danes could relate to, and did explicitly. ${ }^{62}$ Now, the Muslim minority is seen as a threat to Danish society because of media discourses and a lack of familiarity with Muslim people and culture.

\footnotetext{
${ }^{59}$ Quraishy and O’Brien, 115.

${ }^{60}$ Wren, 155.

${ }^{61}$ Andrew Buckser, “Chabad in Copenhagen: Fundamentalism and Modernity in Jewish Denmark,” Ethnology, Spring 2005, Vol. 44 Issue 2, 128.

${ }^{62}$ Buckser (2001), 20.
} 
At the same time, the Muslim minority represents a symbol of the unravelling of Danish society as it has existed for the past fifty years. ${ }^{63}$ Many compromises have been made over the last twenty years, both in surrendering powers to a centralized, professional, bureaucratic, multi-ethnic European authority, anathema to Grundtvigians; compromising the welfare state in a variety of ways in the face of international economic problems and competition; and changing the face of Danish homogeneity with the introduction of many immigrants with different cultural understandings. These factors are all confronting the Grundtvigian orthodoxy in ways that are very disturbing for those raised in its comforting embrace. Hence, the difficulty with its most visible symbol, the presence of relatively large immigrant populations. The religious factor in difficulties with Muslims is likely not as important as the fact that this happens to be the largest widely identifiable group. ${ }^{64}$

However, the seeming ease with which Denmark has adapted to some of these changes is leading to an increasing acceptance of change. ${ }^{65}$ Danes seem to be slowly adjusting to the reality of European integration and economic globalization in their own very Danish way. Although not all sectors of society are doing so, as shown by the continued success of the Danish Peoples’ Party, new developments such as Naser Khader's pro-immigration New Alliance Party, and the increasing popularity of European Monetary Union and other EU projects, and a surprising new acceptance of NATO, show an increasing acceptance of a new form of modernity and transformation of the Danish state. Although the picture is muddled, to generalize, it seems that an urbanized, educated, white-collar elite is driving the changes, while an older blue collar population clings to a more traditional concept of Denmark. The last major division in Danish political culture was centred around a "people” versus “elite” discourse, which may be returning to the fore now, centred around the general issue of whether to open Denmark up to the rest of the world and Europe, through the EU, its institutions, immigration, and other aspects of globalization, or to keep it relatively self contained, ruled strictly by its

\footnotetext{
${ }^{63}$ Linde-Laursen (2007), 269.

${ }^{64}$ However, it may be worth investigating the religious dimension of this relationship, as Christianity was enormously influential in the foundation of the Danish identity. Grundtvig was, after all a pastor.

${ }^{65}$ Robert Kuttner, 'The Copenhagen Consensus: Reading Adam Smith in Denmark,' Foreign Affairs 87:2 (March/April 2008): 78-94.
} 
own institutions, rather than the earlier conflict around relations with Germany, German minorities, and the legitimate source of domestic power.

\section{Conclusion}

While distrust of newcomers, especially those with alien cultures, is widespread in the world, and by no means a unique phenomenon in Denmark, some particular features of Danish nationalism help to explain the reaction there, and may indicate further difficulties ahead for Denmark in a globalized era. In other countries with more overtly nationalistic or insular histories, the reaction to foreigners might be more expected, and perhaps easily acknowledged by their populations, and hence more easily discussed and managed. Although Danes have been known for their open-minded attitudes, the arrival of immigrant communities exposes some of the deeper aspects of Danish nationalism, which are often unacknowledged in Denmark. The homogenizing and essentializing of culture that exist, embedded in Danish nationalism, are more evident now than in the past. These are aspects of their culture that many Danes have perhaps not considered much in the past, but now must in order to live up to the government's self-stated goals of engaging in the modern world. Many people consider tensions with Muslims to arise out of the "backward" or insular character of the religion, contrasting with a more enlightened “modern” Danish culture. It will be hard for the country to be as cosmopolitan or dynamic as many, including the current government, would wish unless the xenophobic and insular side of the Danish character is confronted more openly than it is today. This is the central fault line of Danish politics today, and it is a fundamentally restructuring one. Denmark may well change dramatically because of it over the next decades.

The conflict over immigration to Denmark shows how the country is similar to the rest of Europe, but also different. The root causes of the difficulties are fundamentally similar to the rest of Europe. They grow primarily out of the transition from an industrial society to a post-industrial society. The growth of xenophobia arising from the tensions in this transition are common not just to Europe, but are seen around the world. However, its unusual virulence across an apparently inclusive mainstream political spectrum is an 
outgrowth of the egalitarian, folk centred, bottom up, anti-modern ethos that has steered Denmark toward its present state. It is a necessary by-product of that ideology, given its new setting. Contrary to the situation in Sweden, where opposition to the state is a much less engrained part of the national character, Danes have an instinctive opposition to modernization and centralization. In Denmark Muslim immigration has come to represent a modernization which many feel threatens the traditions of their state, whereas in Sweden this symbolism is much less potent, perhaps explaining the more muted character of xenophobic discourses there, and the failure of Radical Right Wing Populist Parties. The current conflict over modernization, symbolized in the Muhammed Cartoons Affair, and conflict over immigration, may bring Denmark more into line with broader European norms.

Although Denmark has a reputation as a bastion of equality and civilization, foreign observers would do well to remember the historical roots of this phenomenon. The new less tolerant picture of Denmark emerging, most dramatically from the cartoon controversy, is a logical by-product of the same forces that created egalitarian Denmark. The over-riding national discourse has not changed suddenly; social conditions in the country have changed and for the first time the rigidity of Danish cultural conditioning is readily apparent.

\section{Bibliography}

Anderson, Benedict. Imagined Communities. London: Verso, 1991.

Bagge, Povl. "Nationalisme antinationalisme og nationalfølelse i Danmark omkring 1900.” In Dansk identitetshistorie 3: Folkets Danmark 1949-40, edited by Feldbæk, Ole, 443-467. Copenhagen: Reitzels Forlag, 1992.

Berg, Clarissa, and Peter Hervik. ““Muhammedkrisen.” En politisk magtkamp i dansk journalistisk.' The Academy for Migration Studies in Denmark, AMID Working Paper Series 62/2007 (2007).

Brincker, Benedikte. “A 'Small Great National State’: An Analysis of the Cultural and Political Factors that shaped Danish Nationalism 1760-1870. Journal of Historical Sociology. Vol. 16 Issue 4, (December 2003). p. 407-431.

Billig, Michael. Banal Nationalism. London: Sage, 1995.

Borish, Steven M.. The Land of the Living: The Danish Folk High Schools and 
Denmark’s Non-Violent Path to Modernization. Nevada City: Blue Dolphin Publishing, 1991.

Buckser, Andrew. "Rescue and Cultural Context During the Holocaust: Grundtvigian

Nationalism and the Rescue of Danish Jews,” Shofar 19:2 (2001) p. 1-25.

. "Chabad in Copenhagen: Fundamentalism and Modernity in Jewish

Denmark.” Ethnology. Vol. 44 Issue 2, (Spring 2005) p. 107-145.

Feldbæk, Ole. "Clash of Culture in a Conglomerate State: Danes and Germans in 18th

Century Denmark.” In Clashes of Cultures, edited by Johansen, C.V., and P.E.

Ladewig, 80-93. Odense: Odense University Press, 1992.

Gullestad, Marianne. 'Invisible Fences: Egalitarianism, Nationalism and Racism.' The

Journal of the Royal Anthropological Institute 8:1 (March 2002): 45-63.

Hansen, Lene. "Sustaining sovereignty: the Danish approach to Europe.” In European

Integration and National Identity: The Challenge of the Nordic States, edited by

Hansen, Lene, and Ole Wæver, 50-87. London: Routledge, 2002.

Hervik, Peter. 'The Emergence of Neo-nationalism in Denmark.' In Neo-Nationalism in

Europe and Beyond: Perspectives from Social Anthropology, edited by André Gingrich and Marcus Banks, 92-106. New York: Berghahn Books, 2006.

Hussain, Mustafa. “Islam, Media and Minorities in Denmark.” Current Sociology. Vol. 48(4) (October 2000), 95-116.

Jenkins, Richard. "Not Simple At All: Danish Identity and the European Union.” In An Anthropology of the European Union, edited by Bellier, Irène, and Thomas M. Wilson, 159-178. Oxford: Berg, 2000.

Jensen, Bent. “Thirty years of press debate on 'the foreigners' in Denmark Part I: Migrant and guest workers, 1963-80,” in Immigration to Denmark: International and national perspectives. Eds. David Coleman and Eskil Wadensjö. Aarhus: Aarhus University Press, 1999, 199.

Kitschelt, Herbert and Anthony McGann. The Radical Right in Western Europe: A Comparative Analysis. Ann Arbor: University of Michigan Press, 1995.

Knudsen, Tim. Da demokrati blev til folkestyre: Dansk demokratihistorie I. Copenhagen: Akademisk Forlag A/S, 2001.

Kriesi, Hanspeter., R. Koopmans, J.W. Duyvendak and M.G. Giugni. New Social Movements in Western Europe. A Comparative Analysis. Minneapolis, MN: University of Minnesota Press, 1995.

Kuttner, Robert, “The Copenhagen Consensus: Reading Adam Smith in Denmark.” Foreign Affairs 87:2 (March/April 2008): 78-94.

Linde-Laursen, Anders. 'Is something rotten in the state of Denmark? The Muhammad cartoons and Danish political culture.' Contemporary Islam 1:3 (2007): 265274.

McAdam, D. 'Conceptual Origins, Current Problems, Future Directions’, in D. McAdam, 
J.D. McCharthy and M.N. Zald (eds.), Comparative Perspectives on Social Movements: Political Opportunities, Mobilizing Structures, and Cultural Framings. Cambridge: Cambridge University Press, 1996.

Nissen, Henrik S.. "Folkelighed og frihed 1933: Grundtvigianernes reaktion på modernisering, krise og nazisme.” In Dansk identitetshistorie 3: Folkets Danmark 1949-40, edited by Feldbæk, Ole, 587-673. Copenhagen: Reitzels forlag, 1992.

Pedersen, Søren. “Migration to and from Denmark during the period 1960-97,” in Immigration to Denmark: Intrenational and national perspectives. Eds. David Coleman and Eskil Wadensjö. Aarhus: Aarhus University Press, 1999.

Pred, Allan. Even in Sweden: Racism, Racialized Spaces, and the Popular Geographical Imagination. Berkeley: University of California Press, 2000.

Quraishy, Bashy and Tim O’Connor. “Denmark: no racism by definition.” Race \& Class, 32 (3) (1991), 114-119.

Rennie, David. “How Clerics Spread Hatred over Cartoons,” The Daily Telegraph, 7 February 2006, p. 12.

Rose, Flemming. “Muhammed’s ansigt” [Muhammad’s face]. Jyllands-Posten, 30 September 2005, p. 3.

Rydgren, Jens. Movements of Exclusion. Hauppage: Nova Science Publishers, 2005. . "Explaining the Emergence of Radical Right-Wing Populist Parties: The Case of Denmark.” West European Politics Vol. 27:3 (May 2004), 472-502. . 'Radical Right Populism in Sweden. Still a Failure, but for How Long?', Scandinavian Political Studies, 26:1, (2002) , 26-57.

. 'Mesolevel Reasons for Racism and Xenophobia. Some Converging and Diverging Effects of Radical Right Populism in France and Sweden', European Journal of Social Theory, 6:1, (2003), 45-68.

Skidmore-Hess, Daniel. “The Danish Party System and the Rise of the Right in the 2001 Parliamentary Election.” International Social Science Review, Vol. 78 Issue 3/4, (2003) p. 89-110.

Stabler, Ernest. Innovators in Education 1830-1980. Edmonton: University of Alberta Press, 1986.

Stenius, Henrik. "The Good Life is a Life of Conformity: The Impact of Lutheran Tradition on Nordic Political Culture.” In The Cultural Construction of Norden, edited by Sørensen, Øystein, and Bo Stråth, 161-172. Oslo: Scandinavian University Press, 1997.

Sørensen, Øystein and Bo Stråth. "Introduction,” The Cultural Construction of Norden, Oslo: Scandinavian University Press, 1997, 1-24.

Wren, Karen. “Cultural racism: something wrotten in the state of Denmark?” Social and 
Cultural Geography, Vol. 2 No. 2 (2001), 145.

Yahil, L. "National pride and defeat: A comparison of Danish and German nationalism." Journal of Contemporary History, Sep. 91, Vol. 26 Issue 3/4, .

Østergaard-Nielsen, Eva. "Counting the Cost: Denmark’s Changing Migration Policies.” International Journal of Urban and Regional Research, Volume 27.2 (June 2003), 448-454.

Østergård, Uffe. “The Danish Path to Modernity,” Thesis Eleven 77 (May 2004), p. 2543. 